\title{
IMPLEMENTASI PROJECT BASED LEARNING (PjBL) BERPENDEKATAN SCIENCE EDUTAINMENT TERHADAP KREATIVITAS PESERTA DIDIK
}

\author{
Sekar Dwi Ardianti ${ }^{\circledR}$, Ika Ari Pratiwi², Mohammad Kanzunnudin ${ }^{3}$ \\ ${ }^{1,2}$ Prodi Pendidikan Guru Sekolah Dasar FKIP Universitas Muria Kudus, Indonesia \\ ${ }^{3}$ Prodi Pendidikan Bahasa dan Sastra Indonesia FKIP Universitas Muria Kudus, Indonesia
}

\begin{tabular}{|c|c|}
\hline Info Artikel & Abstract \\
\hline Sejarah Artikel: & \multirow{9}{*}{$\begin{array}{l}\text { The development of science and technology gives effect to the development of human resources. } \\
\text { Education has a decisive role for the development and realization of human resources according } \\
\text { to the demands of the times. One of the basic education that should be mastered by students is a } \\
\text { science because science can not be separated from everyday human life. Science as the } \\
\text { proceedings applies the scientific method to solve problems and discover new concepts. In the } \\
\text { process of inquiry or discovery are required special skills in thinking and acting. One of the } \\
\text { capabilities that need to be developed is the ability of students to think creatively. This study was } \\
\text { aimed at examining the effect of the the project based learning by science edutainment approach } \\
\text { on students creativity. This study used the post-test control group design. This study used cluster } \\
\text { random sampling to devide samples into two groups. The experimental group was implemented } \\
\text { model of project based learning by science edutainment approach and the control group was } \\
\text { implemented conventional method. The independent variables in this study are the type of } \\
\text { learning method and dependent variable is the students creativity. The average of students } \\
\text { creativity score in experimental group is } 7,52 \text { and } 6,78 \text { for control group. The t-test showed a } \\
\text { significantly different students creativity, between the experimental and control groups. The use } \\
\text { of project based learning by science edutainment approach significantly influenced the students } \\
\text { creativity. }\end{array}$} \\
\hline Diterima Maret 2017 & \\
\hline Disetujui Mei 2017 & \\
\hline Dipublikasikan Juni 2017 & \\
\hline Keywords: & \\
\hline Project Based Learning, & \\
\hline Science Edutainment, & \\
\hline & \\
\hline & \\
\hline
\end{tabular}

\begin{abstract}
Abstrak
Perkembangan ilmu pengetahuan dan teknologi memberikan pengaruh terhadap perkembangan sumber daya manusia. Pendidikan memiliki peranan dalam menentukan perkembangan dan perwujudan sumber daya manusia sesuai tuntutan zaman. Ilmu dasar yang seharusnya dikuasai oleh peserta didik adalah sains karena keberadaan sains tidak dapat dipisahkan dari kehidupan sehari-hari. Sains sebagai proses inkuiri menerapkan metode ilmiah dalam memecahkan permasalahan dan menemukan konsep baru. Dalam proses inkuiri atau penemuan diperlukan kemampuan khusus dalam berfikir maupunbertindak. Salah satu kemampuan yang perlu dikembangkan adalah kemampuan siswa untuk berfikir kreatif. Tujuan penelitian ini adalah mengkaji pengaruh project based learning (PjBL) berpendekatan science edutainment terhadap kreativitas peserta didik. Penelitian ini menggunakan post test control group design. Penelitian ini menggunakan cluster random sampling untuk menentukan dua kelompok penelitian. Kelompok eksperimen diberikan pembelajaran dengan model PjBL berpendekatan science edutainment dan kelompok kontrol diberikan pembelajaran secara konvensional. Variabel bebasdalam penelitian ini adalah macam metode pembelajaran dan variabel terikatnya adalah kreativitas peserta didik. Ratarata skor kreativitas peserta didik pada kelompok eksperimen adalah 7,52 dan 6,78 untuk kelompok kontrol. Hasil uji-t menunjukkan terdapat perbedaan signifikans pada kreativitas peserta didik antara kelompok eksperimen dan kelompok kontrol. Penggunaan PjBL berpendekatan science edutainment memberikan pengaruh yang signifikans terhadap kreativitas peserta didik.
\end{abstract}

(C) 2017 Universitas Muria Kudus

\begin{tabular}{l}
\hline Alamat korespondensi: \\
Program Studi Pendidikan Guru Sekolah Dasar \\
Fakultas Keguruan dan Ilmu Pendidikan Universitas Muria Kudus \\
Kampus UMK Gondangmanis, Bae Kudus Gd. L. 1t I PO. BOX 53 \\
Tlp (0291) 438229 ex.147 Fax. (0291) 437198 \\
E-mail: $\underline{\text { sekar.dwi.ardianti@umk.ac.id }}$
\end{tabular}

p-ISSN 2087-9385

e-ISSN 2528-696X 


\section{PENDAHULUAN}

Tuntutan bagi sebuah negara berkembang seperti Indonesia untuk mampu bersaing dengan negara maju salah satunya menyiapkan sumber daya manusia yang memiliki daya saing tinggi. Sumber daya manusia yang cerdas, cakap, kreatif, beriman, dan berakhlak mulia merupakan sumber daya manusia yang diharapkan ada pada negara berkembang. Perubahan zaman yang berpengaruh terhadap perkembangan ilmu pengetahuan dan teknologi memaksa Indonesia untuk mampu mempersiapkan sumber daya manusia yang berdayasaing tinggi. Perubahan zaman yang terjadi menuntut manusia memiliki pemikiran yang kreatif dalam kehidupan seharihari. Pendidikan sebagai salah satu cara yang dapat dilakukan pemerintah untuk mempersiapkan sumber daya manusia yang memiliki daya saing tinggi. Menurut Azhari (2013) menyatakan bahwa pendidikan menentukan perkembangan serta perwujudan sumber daya manusia khususnya pada pembangunan bangsa dan negara. Pendidikan memiliki peranan yang penting dalam membentuk sumber daya manusia yang cerdas, cakap, kreatif, beriman, dan berakhlak mulia. Hal tersebut juga tertuang dalam tujuan pendidikan nasional yang mengharapkan pendidikan dapat mengembangkan potensi peserta didik agar bertakwa, berbudi luhur, berilmu, cerdas, kreatif, melek teknologi serta berakhlak mulia.

Sains sebagai salah satu bidang mata pelajaran dasar yang harus dikuasai oleh setiap peserta didik karena sains sebagai ilmu tentang proses yang terjadi dalam kehidupan sehari-hari. Keberadaan sains tidak dapat dipisahkan dari kehidupan manusia. Menurut Kemendikbud (2013) sains tidak hanya sekedar kumpulan pengetahuan namun sains juga termasuk dalam proses penemuan serta cara untuk memperolah pengetahuan tentang alam yang dilakukan secara sistematis. Sains diperoleh dengan cara pengumpulan data berdasarkan penyelidikan, pengamatan serta deduksi untuk memperoleh suatu penjelasan yang dapat dipercaya (Widiyatmoko, 2012). Sains menerapkan proses inkuiri dalam memecahkan permasalahan untuk menemukan sebuah konsep baru. Dalam pembelajaran sains yang menerapkan proses inkuiri atau penemuandi dalamnya diperlukan kemampuan khusus dalam berfikir maupun bertindak yang mendukung dalam proses pemecahan masalah untuk menemukan konsep baru.

Salah satu kemampuan yang perlu dikembangkan adalah kemampuan peserta didik dalam berpikir kreatif. Kreativitas sebagai salah satu kemampuan yang diperlukan oleh peserta didik dalam membantu untuk memecahkan permasalahan dan menemukan konsep baru. Kreativitas merupakan kemampuan peserta didik dalam menciptakan sesuatu yang baru dalam kegiatan belajarnya (Titu, 2015). Kreativitas sebagai kemampuan berpikir divergen atau cara memecahkan suatu permasalahan dengan menggunakan berbagai macam alternatif jawaban terhadap persoalan yang sama benarnya. Putra (2012) berpendapat bahwa kreativitas peserta didik sebagai suatu kemampuan peserta didik untuk menghasilkan macam-macam ide melalui proses berfikir yang luas dan beragam. Penanaman kebiasaan untuk berpikir kreatif perlu diterapkan melalui proses pembelajaran khususnya dalam pembelajaran sains. Guru sebagai seorang yang memegang peran dalam proses pembelajaran dan berinteraksi langsung dengan peserta didik sudah seharusnya dapat menanamkan kebiasaan berpikir kreatif pada peserta didik.

Students centered learning sebagai sebuah pendekatan yang seharusnya digunakan oleh guru untuk pedoman dalam mendesain kegiatan pembelajaran. Guru sebaiknya mendesain kegiatan pembelajaran yang dapat mengaktifkan peserta didik serta dapat mengembangkan potensi yang dimiliki oleh setiap peserta didik. Project based learning (PjBL) merupakan salah satu model pembelajaran dengan ciri khusus adanya kegiatan merancang dan melakukan sebuah proyek di dalamnya untuk menghasilkan sebuah produk. Model pembelajaran ini memberikan pengalaman belajar secara langsung kepada peserta didik melalui kegiatan pembuatan proyek yang berujung pada terciptanya sebuah produk. Menurut Hutasuhut (2010) menyatakan bahwa dalam PjBL peserta didik dituntut untuk menggunakan segalam potensinya dalam memecahkan permasalahan dalam penyelesaian tugas. Adanya kegiatan merancang dan membuat sebuah proyek akan mendukung berkembangnya potensi yang dimiliki oleh masing-masing peserta didik.

Proses pembelajaran sains selain berpendekatan students centered learning juga diharapkan pembelajaran yang dilakukan menarik dan meyenangkan serta mampu menciptakan interaksi antara peserta didik dengan lingkungan sekitar secara langsung. Menciptakan sebuah pembelajaran yang menarik dan menyenangkan bagi peserta didik sangat diharapkan dapat dilakukan oleh semua guru. Hal tersebut dikarenakan sifat alamiah yang dimiliki oleh anak salah satunya adalah bermain. 
Edutainment sebagai pembelajaran dengan cara belajar yang dikemas secara menarik dan menyenangkan melalui kegiatan, media, ataupun bahan ajar yang digunakan tanpa melupakan tujuan pembelajaran yang akan dicapai. Taufiq (2014) berpendapat bahwa pembelajaran dengan pendekatan science edutainment mengajak peserta didik melakukan kegiatan pembelajaran melalui permainan yang mendidik sehingga pembelajaran yang dilakukan terasa lebih menyenangkan. Melalui kegiatan pembelajaran yang bernuansa hiburan diharapkan peserta didik dapat dapat mengaplikasikan pembelajaran secara langsung dalam suasana belajar tanpa tekanan. Proses pembelajaran tanpa tekanan diharapkan diharapkan dapat memberikan kenyamanan peserta didik dalam belajar serta dapat menumbuhkan motivasi peserta didik terhadap pembelajaran yang dilakukan.

Berdasarkan hasil observasi pembelajaran cenderung dilakukan dengan metode ceramah. Guru belum menggunakan model pembelajaran yang bervariasi. Guru cenderung mendominasi kegiatan pembelajaran dengan memberikan materi secara ceramah. Pembelajaran tidak dilakukan dengan kegiatankegiatan yang mengajak peserta didik berpikir kreatif, sehingga kreativitas peserta didik cenderung rendah. Hal tersebut juga dikarenakan guru hanya menekankan kemampuan kognitif peserta didik tanpa diimbangi dengan keterampilan yang dapat meningkatkan daya kreativitas peserta didik. Pada dasarnya kemampuan peserta didik dalam menghafal konsep cukup baik, namun peserta didik belum mampu menunjukkan kreativitas dalam kehidupan sehari-hari.

Penerapan model project based learning (PjBL) dengan pendekatan science edutainment diharapkan dapat meningkatkan kreativitas peserta didik sekolah dasar. Tujuan dalam penelitian ini adalah menguji pengaruh penerapan $\mathrm{PjBL}$ berpendekatan science edutainment terhadap kreativitas peserta didik.

\section{METODE PENELITIAN}

Penelitian ini merupakan penelitian penelitian quasi eksperimen menggunakan control group post test design sebagai desain penelitian ini. Dalam penelitian ini peneliti menggunakan kelompok kontrol sebagai kelompok acuan dan kelompok eksperimen sebagai kelompok yang diberikan perlakuan. Pada kelompok kontrol diberikan pembelajaran dengan pembelajaran ceramah dan kelompok eksperimen diberikan pembelajaran dengan menggunakan model project based learning
(PjBL) berpendekatan science edutainment. Pada akhir pembelajaran kedua kelompok tersebut kemudian diberikan tes akhir (posttest) untuk dibandingkan hasilnya antara kedua kelompok tersebut.

Populasi yang digunakan dalam penelitian ini adalah peserta didik kelas IV Tahun Pelajaran 2016/2017. Pengambilan sampel dalam penelitian ini menggunakan teknik classter random sampling dan sampel yang digunakan adalah peserta didik kelas IV SD sebanyak 2 kelas yang diasumsikan homogen dan normal. Pada penelitian ini peneliti mengambil dua kelas untuk digunakan sebagai kelas eksperimen dan kelas kontrol. Kelas yang digunakan sebagai kelas eksperimen adalah kelas IVA sedangkan kelas yang digunakan sebagai kelas kontrol adalah IVB. Kelas eksperimen diberikan perlakuan yaitu pembelajaran yang menggunakan model project based learning (PjBL) berpendekatan science edutainment, sedangkan kelas kontrol menggunakan pembelajaran langsung sesuai yang biasa dilakukan oleh guru. Variabel bebas penelitian ini adalah macam model pembelajaran yang digunakan yaitu model pembelajaran project based learning berpendekatan science edutainment dan model pembelajaran langsung yang biasa dilakukan oleh guru. Variabel terikat yang digunakan dalam penelitian adalah kreativitas peserta didik pada pembelajaran sains. Data yang diambil dalam penelitian yang dilakukan adalah data kreativitas peserta didik dengan teknik observasi. Instrumen yang digunakan dalam pengambilan data kreativitas peserta didik adalah lembar observasi dalam bentuk cecklist. Data yang diperoleh dianalisis secara statistik dengan uji perbedaan rata-rata.

\section{HASIL DAN PEMBAHASAN}

Hasil dari penelitian yang dilakukan berupa skor kreativitas peserta didik yang diperoleh dari observasi selama proses pembelajaran dengan menggunakan lembar observasi kreativitas peserta didik. Kreativitas yang dikembangkan oleh siswa kelas IV SD Muhammadiyah adalah dengan membuat album edukatif pada pelajaran IPA materi Daur Hidup Hewan. Rekapitulasi skor kreativitas peserta didik secara klasikal pada setiap butir aspek kreativitas disajikan pada Tabel 1 berikut ini.

Tabel 1. Rekapitulasi skor kreativitas siswa pada masing-masing aspek. 


\begin{tabular}{|c|c|c|}
\hline \multirow{2}{*}{$\begin{array}{l}\text { Rata-rata } \\
\text { (Aspek) }\end{array}$} & \multicolumn{2}{|c|}{$\begin{array}{l}\text { Skor Kreativitas Peserta } \\
\text { Didik }\end{array}$} \\
\hline & $\begin{array}{l}\text { Kelas } \\
\text { Eksperimen }\end{array}$ & $\begin{array}{l}\text { Kelas } \\
\text { Kontrol }\end{array}$ \\
\hline Berfikir & 2,05 & 1,91 \\
\hline Keluwesan & 1,89 & 1,56 \\
\hline Perincian & 1,82 & 1,64 \\
\hline Keaslian & 1,76 & 1,67 \\
\hline Total & 7,52 & 6,78 \\
\hline \multicolumn{3}{|c|}{$\begin{array}{l}\text { aspek kreativitas diperoleh berdasarkan hasil } \\
\text { lembar observasi dalam bentuk cecklist. Cecklist } \\
\text { yang digunakan berisi } 10 \text { item soal yang berasal } \\
\text { dari pengembangan dari } 4 \text { aspek kreativitas } \\
\text { peserta didik. Aspek yang dikembangkan dalam } \\
\text { mengukur kreativitas pada peserta didik kelas IV } \\
\text { SD Muhammadiyah Kudus yaitu: 1) Fluency of } \\
\text { thinking atau kelancaran berpikir pada kelas } \\
\text { eksperimen memperoleh hasil 2,05 sedangkan } \\
\text { kelas kontrol memperoleh hasil 1,91; 2) } \\
\text { Flexibility atau keluwesan pada kelas eksperimen } \\
\text { memperoleh hasil } 1,89 \text { sedangkan kelas kontrol } \\
\text { memperoleh hasil } 1,56 \text {; } 3 \text { ) Elaboration atau } \\
\text { perincian pada kelas eksperimen memperoleh } \\
\text { hasil 1,82 sedangkan kelas kontrol memperoleh } \\
\text { hasil 1,64; dan 4) Originality atau keaslian pada } \\
\text { kelas eksperimen memperoleh hasil } 1,76 \\
\text { sedangkan kelas kontrol memperoleh hasil } 1,67 \text {. } \\
\text { peserta didik pada kelas eksperimen dan kelas } \\
\text { kontrol disajikan pada Tabel } 2 \text { berikut ini. } \\
\text { Tabel 2. Rekapitulasi skor kreativitas siswa }\end{array}$} \\
\hline \multirow{2}{*}{ Komponen } & \multicolumn{2}{|c|}{$\begin{array}{l}\text { Skor Kreativitas Peserta } \\
\text { Didik }\end{array}$} \\
\hline & $\begin{array}{l}\text { Kelas } \\
\text { Eksperimen }\end{array}$ & $\begin{array}{l}\text { Kelas } \\
\text { Kontrol }\end{array}$ \\
\hline Rata-rata & 7,52 & 6,78 \\
\hline $\begin{array}{l}\text { Skor } \\
\text { tertinggi }\end{array}$ & 10 & 9 \\
\hline $\begin{array}{l}\text { Skor } \\
\text { terendah }\end{array}$ & 4 & 5 \\
\hline
\end{tabular}

Hasil perolehan skor kreativitas peserta didik diketahui bahwa pada kelas eksperimen memperoleh skor kreativitas lebih tinggi apabila dibandingkan dengan skor kreativitas pada peserta didik kelas kontrol. Hal tersebut dapat dilihat pada skor rata-rata kreativitas peserta didik kelas eksperimen mencapai 7,52 sedangkan kelas kontrol mencapai 6,78. Skor kreativitas peserta didik tersebut selanjutnya dianalisis secara statistik dengan uji-t. Pengujian secara statistik menggunakan uji-t dilakukan untuk mengetahui ada tidaknya perbedaan skor kreativitas peserta didik pada kelas eksperimen dan kelas kontrol. Hasil uji-t menunjukkan bahwa nilai t-hitung 2,081 > t- tabel 2, 011. Nilai tersebut menunjukkan bahwa terdapat perbedaan yang signifikan antara skor kreativitas kelas ekperimen dengan kelas kontrol.

Kreativitas peserta didik pada kegiatan pembelajaran dengan model project based learning ( $\mathrm{PjBL})$ berpendekatan science edutainment pada peserta didik kelas IV di SD Muhammadiyah Kudus tampak pada hasil album yang dibuatnya secara berkelompok. Kegiatan peserta didik dalam membuat album edukatif materi Daur Hidup Hewan. Peserta didik diberikan kebebasan dalam mendesain album edukatif yang dibuat dengan imajinasi dan kreativitasnya. Peserta didik menuangkan ide kreatifnya dalam bentuk album edukatif Daur Hidup Hewan. Kreativitas peserta didik dalam mengembangkan album edukatif tampak pada beberapa foto di bawah ini.

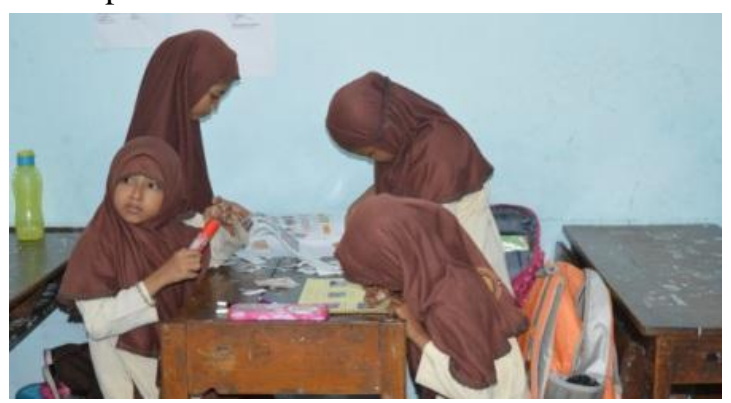

Gambar 1. Siswa berkelompok membuat album sesuai kreativitasnya

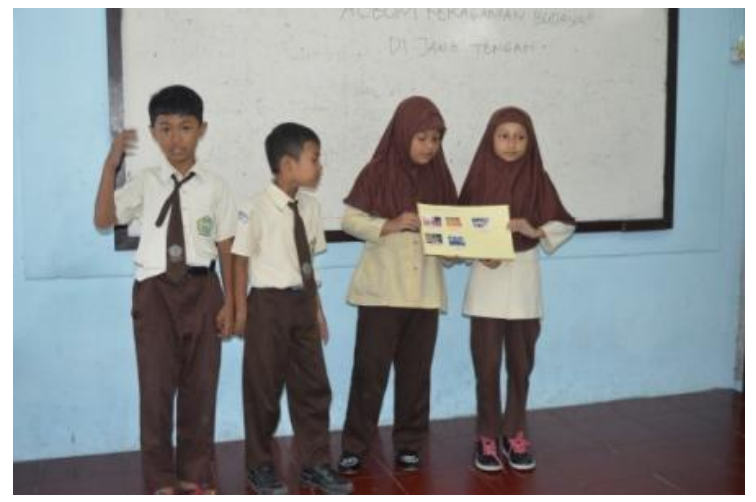

Gambar 2. Siswa mempresentasikan album hasil kreativitasnya

Perbedaan skor kreativitas antara kelas eksperimen dan konrol dikarenakan penerapan model pembelajaran yang berbeda. Penerapan model project based learning (PjBL) berpendekatan science edutainment dalam pembelajaran memberikan pengaruh positif terhadap kreativitas peserta didik. Titu (2015) menyatakan bahwa project based learning (PjBL) dapat mendorong peserta didik untuk meningkatkan kreativitasnya melalui kegiatan menghasilkan produk dalam bentuk yang nyata 
yang dapat meningkatkan kreativitas peserta didik. Model project based learning (PjBL) mengajak peserta didik untuk aktif dalam kegiatan pembelajaran sedangkan peran guru hanya sebagai fasilitator dan evaluator produk yang dihasilkan oleh peserta didik. Selain itu, penerapan model berpendekatan science edutainment membantu project based learning peserta didik dalam memperoleh informasi melalui kegiatan eksplorasi ketika membuat sebuah produk. Wena (2011: 145) berpendapat bahwa project based learning sebagai sebuah model pembelajaran yang dapat melibatkan peserta didik dalam transfer pengetahuan. Penerapan model project based learning (PjBL) mengajak peserta didik untuk menghasilkan produk sehingga dapat meningkatkan kreativitas peserta didik.

Hasil observasi masing-masing item penilaian kreativitas dari kelompok eksperimen dapat dilihat pada Tabel 3 berikut ini. untuk belajar menghasilkan sebuah karya dalam suasana pembelajaran yang menyenangkan sesuai dengan tingkat perkembangan peserta didik. Menurut Peserta didik tidak merasa terbebani dengan kegiatan pembuatan produk. Ardianti (2017) menyatakan bahwa kegiatan pembelajaran dengan pendekatan science edutainment menjadikan pembelajaran lebih menyenangkan bagi peserta didik. Kegiatan pembuatan produk membuat peserta didik lebih antusias dalam pembelajaran dan berlomba lomba untuk menghaslkan produk terbaik. Hal tersebut sesuai dengan pendapat Titu (2015:179) menyatakan bahwa dengan pembelajaran yang menerapkan project based learning mengajak peserta didik untuk aktif dalam pembelajaran. Berdasarkan hasil observasi juga menunjukkan sebanyak $85,2 \%$ dari seluruh peserta didik di kelompok eksperimen berperan aktif dalam kegiatan pembuatan produk.

Pembelajaran dengan project based

Tabel 3. Rekapitulasi hasil observasi kreativitas di kelompok eksperimen

\begin{tabular}{llll}
\hline \multirow{2}{*}{ No } & Aspek Yang Diamati & \multicolumn{2}{l}{ Persentase (\%) } \\
\cline { 3 - 4 } & & Eksperimen & Kontrol \\
\hline 1. & Peserta didik berpartisipasi aktif dalam kegiatan pembuatan produk & 85,2 & 73,9 \\
2. & Peserta didik memiliki rasa ingin tahu yang tinggi & 77,8 & 65,2 \\
3. & Peserta didik berani menyatakan pendapat / keinginannya dalam kegiatan & 92,6 & 69,6 \\
& pembuatan produk & & 78,3 \\
4. & Peserta didik berdiskusi dengan akrab dalam kelompok & 85,2 & 73,9 \\
5. & Peserta didik memiliki keasyikan dalam kegiatan pembuatan produk & 96,3 & 65,2 \\
6. & Peserta didik memberikan ide kreatif dalam kegiatan pembuatan produk & 88,9 & 65,2 \\
7. & Peserta didik memiliki sikap kritis dalam kegiatan pembuatan produk & 77,8 & 60,9 \\
8. & Peserta didik memiliki inisiatif dalam kegiatan pembuatan produk & 85,2 & 69,6 \\
9. & Peserta didik memiliki sikap disiplin dalam kegiatan pembuatan produk & 77,8 & 73,9 \\
10. & Peserta didik ulet dalam kegiatan pembuatan produk & 92,6 & \\
\hline
\end{tabular}

Tabel di atas menunjukkan bahwa secara keseluruhan persentase dari masingmasing item pada lembar observasi kreativitas peserta didik pada kelompok eksperimen memperoleh skor yang lebih tinggi dibandingkan skor yang diperoleh peserta didik pada kelompok kontrol. Persentase tertinggi pada kelompok eksperimen terdapat dalam aspek keasyikan peserta didik dalam kegiatan pembuatan produk. Sebanyak 96,3\% peserta didik pada kelompok eksperimen berdasarkan pengamatan terlihat asyik atau nyaman dalam kegiatan pembuatan produk. Hal tersebut dikarenakan penerapan model project based learning berpendekatan science edutainment mengajak peserta didik learning dengan pendekatan science edutainment menjadikan peserta didik untuk memiliki inisiatif dan cara berpikir kreatif. Melalui penerapan model project based learning dengan pendekatan science edutainment mengajak peserta didik membuat sebuah produk dengan memberikan kebebasan peserta didik dalam mengeksplore beberapa cara kreatif dalam pembuatan produk. Sebanyak 88,9\% peserta didik kelompok eksperimen memberikan ide kreatifnya dalam pembuatan produk. Kreativitas peserta didik dilihat dari kemampuan peserta didik memberikan inisiatif dari pembuatan produk. Menurut Subur (2013:50) kreativitas sebagai kemampuan untuk melihat kemungkinan kemungkinan yang dapat dilakukan dalam 
memecahkan permasalahan maupun menemukan konsep baru. Titu (2015:185) menyatakan bahwa penerapan model project based learning sangat mendukung kreativitas peserta didik. Hal tersebut juga dapat dilihat bahwa sebanyak $85,2 \%$ peserta didik kelompok eksperimen memiliki inisiatif dalam pembuatan produk yang berdampak positif terhadap peningkatan kreativitas peserta didik.

\section{SIMPULAN}

Berdasarkan hasil penelitian dapat disimpulkan bahwa model project based learning dengan pendekatan science edutainment dapat meningkatkan kreativitas siswa ditunjukkan dengan hasil uji-t. Berdasarkan uji $t$ menunjukkan bahwa terdapat perbedaan yang signifikans antara kreativitas kelompok kontrol dan kelompok eksperimen. Hal tersebut berarti bahwa penerapan model PjBL berpendekatan science edutainmentmemberikan efek nyata terhadap kreativitas siswa. Model PjBL berpendekatan science edutainment dapat diterapkan pada pembelajaran science guna memberikan variasi pembelajaran dan diharapkan juga mampu memberikan dampak positif terhadap peningkatan hasil belajar siswa.

\section{DAFTAR PUSTAKA}

Ardianti SD, Wanabuliandari S \& Rahardjo S. Peningkatan Perilaku Peduli Lingkungan dan Tanggung Jawab Siswa melalui Model EJAS dengan Pendekatan Science Edutainment. Jurnal Pendidikan Dasar. 4(1) 1-7.

Azhari. 2013. Peningkatan Kemampuan Berfikir Kreatif Matematik Siswa Melalui Pendekatan Konstruktivisme Di Kelas VII Sekolah Menengah Pertama (SMP) Negeri 2 Banyuasin III. Jurnal Pendidikan Matematika. 7(2) hlm.1-11

Kemendikbud. 2013. Modul Pelatihan Implementasi Kurikulum 2013 - Materi Pelatihan Guru - Implementasi Kurikulum 2013 - SMP/MTs - Ilmu Pengetahuan Alam: Badan Pengembangan Sumber Daya Manusia Pendidikan dan Kebudayaan dan Penjaminan Mutu Pendidikan Kementerian
Pendidikan dan Kebudayaan.

Hutasuhut, S. 2010. Implementasi Pembelajaran Berbasis Proyek (Project Based Learning) untuk Meningkatkan Motivasi dan Hasil Belajar Mata Kuliah Pengantar Ekonomi Pembangunan pada Jurusan Manajemen FE Unimed. Pekbis Jurnal. 2(1) 196-207.

Putra TT, Irwan, \& Vionanda D. 2012. Meningkatkan Kemampuan Berpikir Kreatif Siswa Dengan Pembelajaran Berbasis Masalah. Jurnal Pendidikan Matematika. 1(1) hlm. 22-26.

Subur, Johan. 2013. Analisis Kreativitas Siswa Dalam Memecahkan Masalah Matematika Berdasarkan Tingkat Kemampuan Matematika Di Kelas. Jurnal Penelitian Pendidikan. 14(1) hlm. 49-54.

Susanti. 2013. Pengaruh Pembelajaran Berbasis Proyek Terhadap Kemampuan Berpikir Kreatif dan Sikap Ilmiah Siswa Pada Materi Nutrisi. Jurnal Pengajaran MIPA. 18(1) hlm. 36-42.

Taufiq M, Dewi RN, \& Widyatmoko A. 2014. Pengembangan Pembelajaran IPA Terpadu Berkarakter Peduli Lingkungan Tema "Konservasi" Berpendekatan Science Edutainment. Jurnal Pendidikan IPA Indonesia. 3 (2): 140-145.

Titu, MA. 2015. Penerapan Model Pembelajaran Project Based Learning (PjBL) untuk Meningkatkan Kreativitas Siswa Pada Materi Konsep Masalah Ekonomi. Proseding Seminar Nasional 9 Mei 2015.

Wena, Made. 2011. Strategi Pembelajaran Inovatif Kontemporer; Suatu Tinjauan Konseptual Operasional. Jakarta: Bumi Aksara.

Widiyatmoko A \& Pamelasari SD. 2012. Pembelajaran Berbasis Proyek Untuk Mengembangkan Alat Peraga IPA dengan Memanfaatkan Bahan Bekas Pakai. Jurnal Pendidikan IPA Indonesia. 1(1):51-56. 